\title{
Peran Guru dalam Menanamkan Nilai Toleransi pada Anak Usia Dini di Indonesia
}

\author{
Deffa Lola Pitaloka $^{\varpi}$, Dimyati ${ }^{2}$,Edi Purwanta ${ }^{3}$ \\ Pendidikan Anak Usia Dini, Universitas Negeri Yogyakarta(1) \\ Pendidikan Ilmu Keolahragaan, Universitas Negeri Yogyakarta(2) \\ Pendidikan Luar Biasa, Universitas Negeri Yogyakarta(3) \\ DOI: $10.31004 /$ obsesi.v5i2.972
}

\begin{abstract}
Abstrak
Pendidikan karakter pada anak usia dini merupakan salah satu pondasi yang sangat penting untuk ditanamkan pada diri anak. Lembaga sekolah terutama guru memiliki peran penting dalam mengenalkan. Salah satu nilai karakter yang ditanaman kepada anak adalah toleransi. Penanaman nilai toleransi sejak dini bertujuan agar anak memiliki rasa menghargai keberagaman. Tujuan penelitian ini adalah untuk memaparkan pentingnya peran guru dalam menanamkan nilai toleransi pada anak usia dini di Indonesia. Peneitian menggunakan metode studi literature kajian pustaka dengan mengumpulkan berbagai sumber ilmiah. Hasil penelitian menunjukkan bahwa peran guru dalam menanamkan nilai toleransi pada anak antara lain dengan merancang kurikulum toleransi, memiliki kompetensi yang optimal dan proporsional serta memiliki komitmen yang kuat dalam memberikan teladan kepada anak mengenai nilai-nilai karakter salah satunya nilai toleransi. Peran guru dalam menanamkan nilai toleransi juga dapat melalui kegiatan pembelajaran dengan menggunakan beberapa metode seperti memberikan keteladanan, pemberian arahan, pembiasaan, kegiatan mendongeng, kegiatan permainan, dan penggunaan media.
\end{abstract}

Kata Kunci: peran guru; nilai toleransi, anak usia dini.

\begin{abstract}
Character education toward early childhood is one of the important foundations to be imparted to the children. School institutions, especially teachers, have important roles in introducing to the children. One of the character values that is imparted to the children is tolerance. Imparting tolerance value in early childhood aims to make children have a sense of respecting the diversity. Goals of this research are to expose about teacher's role to impart the tolerance values to early children in Indonesia using lireature review method by gathering various scholar sources. The research results showed that the teachers' roles in imparting tolerance value toward children are designing tolerance curriculum, having optimal and proportional competence, and also having strong commitment in giving examples to the children regarding the character values, which is tolerance. The teachers' roles are also by lesson activity using some methods such as giving examples, guidance, and habitual activities like telling stories, playing games, and using media.
\end{abstract}

Keywords:Teachers' roles; tolerancevalue; earlychildhood.

Copyright (c) 2021 Deffa Lola Pitaloka, Dimyati, Edi Purwanta

$\triangle$ Correspondingauthor:

Email Address : deffa.pitaloka@ymail.com ( Ngemplak, Sleman, Yogyakarta )

Received 16 December 2020, Accepted 31 December 2020, Published 5 January 2021 


\section{PENDAHULUAN}

Pendidikan karakter bagi anak usia dini ditujukan untuk menanamkan nilai-nilai kebaikan agar menjadi suatu kebiasaan ketika anak sudah dewasa atau pada jenjang pendidikan selanjutnya. Pada masa ini anak belum mendapatkan pengaruh negatif yang cenderung banyak berasal dari lingkungan sehingga orangtua maupun pendidik anak usia dini akan sangat lebih mudah membimbing anak untuk memaksimalkan perkembangannya terutama dalam menanamkan nilai-nilai pendidikan karakter(Cahyaningrum et al., 2017). Sebagaimana tujuan pendidikan karakter adalah memberikan tuntunan kepada peserta didik untuk mengembangkan nilai-nilai karakter secara sadar baik di sekolah maupun di lingkungan sekitar (Juanda, 2019).

Terdapat 18 nilai-nilai karakter antara lain yaitu; religius; jujur; toleransi; disiplin; kerja keras; kreatif; mandiri; demokratis; rasa ingin tahu; semangat kebangsaan; cinta tanah air; menghargai prestasi; bersahabat/ komunikatif; cinta damai; gemar membaca; peduli lingkungan; peduli sosial dan tanggung jawab (Putry, 2019). Menurut UNESCO Tahun 1994 toleransi merupakan bagian integral dan esensial untuk realisasi hak asasi manusia dan pencapaian perdamaian. Dalam bentuknya yang paling sederhana dan mendasar toleransi adalah menghormati hak dan identitas orang lain (Ozkul et al., 2018). Toleransi adalah sikap dan tindakan yang menghargai perbedaan agama, suku, etnis, pendapat, sikap dan tindakan orang lain yang berbeda dari diri sendiri. Toleransi adalah kemampuan dan kesediaan seseorang dan masyarakat umum untuk mewaspadai hak-hak kelompok kecil dimana kelompok itu hidup dalam aturan yang ditentukan oleh mayoritas yang merupakan dasar demokrasi (Sahal et al., 2018). Toleransi adalah konsep yang kompleks dan beraneka segi. Toleransi adalah komunikasi dan kebebasan berpikir, hati nurani dan keyakinan, harmoni dalam keanekaragaman, kebijakan yang membuatnya mungkin untuk saling pengertian antara orang, orangtua dan anak melalui hubungan damai bebas konflik (Liulka, 2019).

Penanaman nilai toleransi sejak dini diharapkan dapat menjadikan generasi penerus Bangsa Indonesia menjadi manusia yang memiliki sikap toleransi agar tidak terjadi perpecahan karena suatu perbedaan yang ada di lingkungan masyarakat, mengingat Indonesia adalah salah satu negara dengan keragaman suku, bahasa, agama yang sangat banyak. Indonesia adalah salah satu negara multikultural atau beragam budaya terbesar di dunia, hal ini dapat dilihat dari situasi dan kondisi sosiokultural yang sangat kompleks, beragam dan luas. Indonesia terdiri dari berbagai macam kelompok etnis, budaya, agama yang masing-masing jamak (plural) sekaligus hetegoren. Pluralitas dan heterogenitas pada masyarakat Indonesia diikat dalam semboyan Negara Indonesia yaitu "bhinneka tunggal ika" (Lestari, 2015).

Untuk menjaga sebuah keutuhan suatu Bangsa dengan perbedaan yang beraneka ragam sangat diperlukan rasa toleransi itu sendiri agar tertanam pada benak seluruh masyarakatnya sehingga ancaman perpecahan akibat perbedaan bisa terhindari, justru sebaliknya dengan perbedaan itu masyarakat mampu hidup rukun saling menghormati dan menghargai. Untuk itu nilai toleransi ini harus ditanamkan pada benak semua individu atau masyarakat Indonesia khususnya anak usia dini yang menjadi generasi penerus Bangsa Indonesia.

Nilai dapat disebut sebagai karakteristik yang muncul dan membentuk individu sehingga menjadikan pribadi yang lebih baik. Nilai yang terdapat pada individu akan membentuk dan berubah menjadi pribadi yang diinginkan. Untuk itu, nilai menjadikan individu sebagai dasar dalam berprilaku(Susanto \& Kumala, 2019).

Toleransi merupakan salah satu dari 18 nilai karakter bangsa yang harus dimiliki para siswa di Indonesia termasuk anak usia dini. Menurut Nasution Pembelajaran karakter toleransi harus diimplementasikan sejak dini dikarenakan anak usia dini adalah investasi masa depan bagi keluarga maupun yang lebih luas yaitu nusa dan bangsa (Fatimah, 2018). Menurut Drieltoleransi secara luas dapat diartikan sebagai penerimaan semua perbedaan yang ada di dalam masyarakat (Ozkul et al., 2018). 
Toleransi adalah harmoni dalam perbedaan. Dengan demikian toleransi adalah kesediaan seorang individu dan masyarakat hidup dalam aturan yang sudah ditentukan yang merupakan makna dari demokrasi (Sahal et al., 2018). Sependapat dengan Hjemdkkbahwa toleransi berarti rasa hormat, penerimaan, dan apresiasi terhadap keanekaragaman budaya dunia, bentuk ekspresi, dan cara manusia menjadi manusia (Hjerm et al., 2020). Toleransi juga dapat berarti adalah tindakan menahan diri yang disengaja dalam menghadapi sesuatu yang tidak disukai (Janmaat \& Keating, 2019).

Toleransi dapat dibagi menjadi dua jenis yaitu toleransi aktif dan toleransi pasif. Toleransi aktif adalah sikap yang didasarkan pada pengetahuan, pemahaman dan perspektif. Sedangkan toleransi pasif lebih dibatasi pada pengabaian atau tidak terlalu mengkritisi perbedaan (Schweitzer, 2018). Bentuk toleransi dibagi menjadi dua yaitu toleransi agama dan toleransi sosial. Toleransi agama ialah toleransi yang bersangkutan dengan keyakikan atas agama yang berhubungan dengan sikap menerima untuk member ksempata pemeluk agama lain beribadah menurut ketentuan yang diyakini. Sedangkan toleransi sosial bersangkutan pada bagaimana masyarakat mampu bekerjasama dengan orang lain tanpa melihat perbedaan baik agama, budaya dan lain-lain dengan batas-batas yang telah ditentukan (Salim, 2018).

Dalam menanamkan nilai toleransi pada anak usia dini, peran pendidik dan orangtua adalah yang utama. Pada masa anak usia dini dapat disebut juga dengan masa-masa keemasan atau disebut the golden age (Fadhillah, 2019)Pada masa ini anak memiliki potensi yang sangat baik untuk dikembangkan secara maksimal. Pada masa inilah waktu yang tepat untuk menanamkan nilai-nilai karakter kebaikan salah satunya nilai toleransi yang kelak dapat membentuk kepribadian anak.

Namun jika lingkungan justru menunjukkan hal-hal yang cenderung negatif maka akan berpengaruh buruk pula dengan karakter anak khususnya pada nilai karakter toleransi. Penulis menemukan di lapangan sikap anak yang sudah menunjukkan sikap intoleran yaitu anak tidak mau berteman dengan temannya yang berbeda agama, kemudian anak usia dini sudah melakukan perundungan pada temannya sendiri yang lebih lemah atau berbeda dengan dirinya. Sikap-sikap ini tidak lepas dari pengaruh orangtua dan sekolah. Kenyataannya lagi, fenomena yang sering terjadi yaitu tindakan intoleran yang diberitakan diberbagai media mengenai anak usia dini yang melakukan adegan kekerasan, meniru ujaran kebencian, berbicara tidak sopan. Kondisi ini disebabkan pada masa usia dini, anak sangat cepat menyerap dalam hal meniru, jika lingkungan anak adalah lingkungan dengan sikap intoleran yang tinggi maka akan mempengaruhi anak untuk menirunya (Ananda, 2017).

Dalam artikel Pinter Politik yang ter bit pada tanggal 15 Agustus 2019 memuat berita bahwa pada tahun 2018 Pusat Pengkajian Islam dan Masyarakat (PPIM) Universitas Islam Negeri mengeluarkan hasil survey nasional tentang keberagaman di sekolah dan universitas di Indonesia, hasilnya adalah 56,9\% guru Taman Kanak-Kanak hingga Sekolah Menengah Atas di Indonesia memiliki opini intoleran.

Pada artikel Kompanasia.com yang terbit pada tanggal 19 November 2020 memuat artikel berita tentang peristiwa intoleransi di Sekolah Menengah di Depok. Peristiwa ini mengenai pemilihan ulang ketua OSIS karena ketua OSIS terpilih sebelumnya beragama berbeda. Hal kedua yang memperihatinkan adalah kasus-kasus intoleransi justru dikenalkan pada generasi muda melaui sekolah bahkan PAUD hingga Perguruan Tinggi.

Untuk itu peran lingkungan, keluarga dan sekolah khususnya peran guru sangat penting untuk mendidik karakter anak salah satunya dengan menanamkan nilai toleransi pada anak usia dini agar dimasa yang akan datang anak menjadi manusia dengan sikap toleransi yang tinggi sehingga Indonesia menjadi negara beragam yang kuat dengan masyarakatnya yang berkarakter. Maka pada penelitian ini akan dibahas mengenai pentingnya peran guru dan bagaimana metode ataupun strategi guru dalam menanamkan nilai toleransi pada anak usia dini di Indonesia. Beberapa pertanyaan penelitian yaitu antara lain; apa itu pengertian toleransi yang telah dipaparkan di bagian pendahuluan, kemudian 
penjelasan mengenai apa faktor-faktor yang mempengaruhi toleransi dan apa peran guru dalam menanamkan toleransi pada anak usia dini di Indonesia.

\section{METODE PENELITIAN}

Penelitian ini menggunakan metode studi literasi atau kajian kepustakaan. Metode penelitian ini memiliki sumber dari berbagai macam kumpulan artikel hasil karya ilmiah atau penelitian sebelumnya yang digunakan untuk menjawab pertanyaan penelitian pada artikel ini(Ati, 2015). Penelitian ini menggunakan metode kajian literasi karena bertujuan untuk mengumpulkan hasil-hasil penelitian yang berkaitan dengan peran guru dalam menanamkan nilai toleransi pada anak usia dini di Indonesia. Oleh karena itu penelitian ini berisikan tentang hasil-hasil penelitian mengenai penanaman nilai toleransi dari beberapa daerah yang ada di Indonesia.Sampel pada penelitian ini adalah hasil-hasil penelitian terdahulu mengenai penanaman nilai toleransi pada anak usia dini diberbagai lembaga PAUD yang ada di Indonesia. Pengumpulan data dilakukan dengan memaparkan hasil-hasil penelitian terdahulu tersebut.

Penelitian kepustakaan dapat dipercaya hasilnya dalam menjawab persamalahan penelitian dikarenakan isi dari penelitian kepustakaan adalah kumpulan dari penelitianpenelitian yang sudah dilakukan sebelumnya oleh peneliti lain (Wandi \& Mayar, 2019). Oleh karena itupengumpulan hasil-hasil penelitian terdahulu mengenai penanaman nilai toleransi pada anak usia dini akan memaparkan pentingnya peran guru dalam hal tersebut dan juga mengungkap metode-metode apa saja yang digunakan guru dalam peaksanaanpembeajaran di sekolah . Langkah-langkah dalam melakukan penelitian kepustakaan harus tepat. Berikut adalah langkah-langkah penelitian kajian kepustakaan:

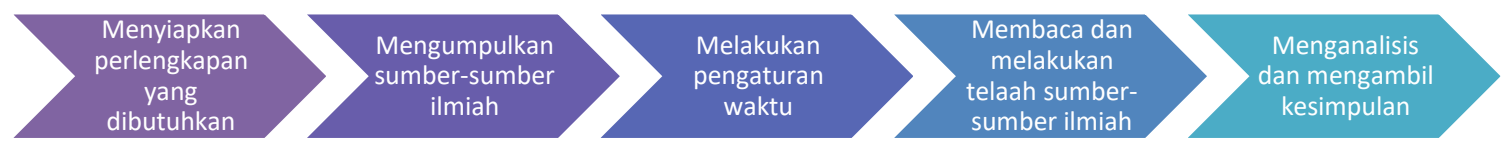

\section{Gambar 1. Langkah-langkah penelitian kajian pustaka}

Sebelum melakukan telaah sumber-sumber ilmiah, peneliti harus mempersiapkan alatalat yang digunakan untuk penelitian, kemudian peneliti menentukan dan mengetahui secara pasti sumber ilmiah yang dibutuhkan. Sumber ini dapat berupa buku, jurnal, dan data atau informasi lainnya yang relevan. Setelah mengumpulkan sumber, peneliti dapat membaca sumber-sumber ilmiah tersebut. Setelah dilakukan telaan maka peneliti mengambil kesimpulan dari berbagai macam kajian yang telah dikumpulkan. Hal-hal inilah yang sejalan dengan langkah langkah studi pustaka (Nasution et al., 2019).

\section{HASIL DAN PEMBAHASAN}

\section{Toleransi pada Pendidikan Anak Usia Dini}

Toleransi adalah salah satu nilai karakter yang sudah harus ditanamkan sejak pendidikan anak usia dini. Salah satu toleransi yang ada ialah toleransi beragama. Toleransi beragama dapat diwujudkan dengan strategi 5k menurut Fidesnirur(Faiqoh, 2015), antara lain yaitu: consensus yaitu ditetapkan kesepakatan bersama antar guru dan orang tua tentang karakter yang akan dibangun; komitmen yaitu ada ketaatan dan tanggung jawab besama oleh guru dan orang tua dalam melaksanakan kesepakatan penerapan sikap pada anak; Konsisten yaitu Ada sikap konsisten dalam menerapkan sikap melalui kegiatan bermain, baik di lembaga PAUD maupun di keluarga; kontinu dilakukan secara berkelanjutan setiap hari, sepanjang tahun hingga perilaku tersebut menjadi kebiasaan selanjutnya terpatri dalam jiwa dan pikiran anak sehingga membentuk sikap; konsekuen: ada konsekuensi yang diterapkan 
dan harus dipatuhi baik oleh guru, orang tua, maupun anak bila terjadi pelanggaran terhadap komitmen pengembangan sikap anak.

Ada beberapa bentuk toleransi yang dapat ditunjukkan pada sikap anak antara lain seperti anak cenderung menunjukkan toleran pada orang lain tanpa menghiraukan perbedaan, menunjukkan penghargaan pada orang dewasa dan figur yang memiliki wewenang, terbuka untuk mengetahui orang dari latar belakang dan keyakinan orang lain yang berbeda, menyuarakan perasaan tidak senang dan rasa peduli ketika ada seseorang yang dihina, membantu teman yang lemah, menahan diri untuk tidak memberika komentar jahat kepada temannya, selalu berpikir positif meskipun banyak perbedaan disekelilingnya(Soraya, 2013).Sebuah penelitian juga menyebukan bahwa toleransi mampu membentuk sikap-sikap menerima berbedaan, mengubah penyeragaman menjadi keragaman, mengakui hak orang lain, menghargai dan menghormati keberadaan orang lain, mendukung dan mengharga perbedaan budaya dan keberagaman lainnya yang diciptakan oleh Tuhan YME (Anang \& Zuhroh, 2019).

Di dalam teori toleransi menurut Sztejnberg dan Jasinnki dibagi menjadi beberapa dimensi yaitu toleransi antarentis, toleransi sosial dan toleransi dalam kepribadian. Dimenasi antaretnis meliputi sikap terhadap perbedaan mengenai kaum mayoritas dan minoritas contohnya saling menghargai perbedaan warna kulit ataupun letak geografis. Dimensi toleransi sosial melitputi interaksi sosial yang terjadi antar individu dengan membangun komunikasi maka terjadinya keterbukaan meskipun ditengah perbedaan. Sedangkan toleransi kepribadian meliputi fenomena atau realita di lingkungan yang berada pada sebuah kebudayaan yang beragam, contohnya sebuah perlakuan antara kedua etnis yang saling menghakimi satu sama lain (Susanto \& Kumala, 2019).

\section{Faktor-faktor yang Mempengaruhi Toleransi}

Faktor-faktor yang mempengaruhi toleransi yang pertama adalah agama dan norma sosial pengaruhnormasosialdan agama bisamenjadi signifikan, jikanormasosialdan agama dapatdikembangkansecarapositifmakaberperanlebihbesardalammembanguntoleransietnis(I dris et al., 2016). Faktor selanjutnya adalah pengasuhan orangtua dan guru. Faktorpenentu untuk nilai toleransi tumbuh pada anak usia dini adalah pendidikan melalui pengasuhan orang tua dan guru (Manoppo et al., 2019). Faktor yang mempengaruhi toleransi lainnya yaitu pendidikan. Berdasarkan hasil penelitian ditemukan bahwa terdapat pengaruh positif dan signifikan dari praktik pendidikan terhadap sikap siswa dalam nilai toleransi (Taş \& Minaz, 2019).Prinsip kerukunan yang dipegang teguh, prinsiphormat dan solidaritas yang tinggi antara sesame juga menjadi faktor pendorong pada toleransi (Faridah, 2013).

Berdasarkan hasil penelitian ditemukan beberapa faktor penyebab terjadinya intoleransi salah satunya dalam kebebasan beragama antara lain yaitu, berbeda pendapat tentang kepercayaan, berselisih dengan etnis lain dengan membawa-bawa agama masingmasing, berselisih karena masalah pribadi dengan membawa-bawa agama, merasa terganggu dengan kegiatan keagamaan yang diselenggarakan disekitar lingkungan permukiman (Prabowo, 2019).

\section{Peran Guru dalam Menanamkan Toleransi pada Anak Usia Dini}

Pendidikan mempunyai fungsi untuk mengembangkan nilai-nilai budaya menjadi nilai-nilai budaya bangsa yang sesuai dengan kehidupan. Pendidikan toleransi sejak dini sangatlah penting untuk diterapkan sejak Pendidikan Anak Usia Dini, baik secara eksplisit maupun implicit. Bagi Maria Harris, kurikulum implisit artinya sesuai yang tidak tertulis tetapi memiliki arti yang sangat penting. Seperti kurikulum yang diterapkan di Sulawesi Utara ini masih bersirat. Namun, para peneliti merekomendasikan pembentukan kurikulum toleransi pada anak usia dini secara eksplisit agar anak mampu belajar dan menerapkan nilai toleransi sejak awal (Manoppo et al., 2019). 
Guru memiliki peran penting dalam bidang pendidikan. Berdasarkan UndangUndang RI Nomor 14 Tahun 2005 Bab 2 Pasal 4 Tentang Guru dan Dosen, seorang guru memiliki tuga, antara lain: guru sebagai pendidik, guru adalah seorang pendidik yang menjadi tokoh dan panutan bagi peserta didik dan lingkungannya; guru sebagai pelajar, guru bertugas untuk membantu peserta didik dalam meneruskan dan mengembangkan ilmu dan teknologi. Untuk itu, guru harus mengikuti perkembangan teknologi agar pengajarannya mengikuti zaman terkini; guru sebagai pembimbing, sebagai pembimbing seorang guru dansiswa diharapkan ada kerja sama yang baik dalam merumuskan tujuan pembelajaran; guru sebagai pengarah, seorang guru diharapkan dapat mengarahkan peserta didiknya dalam memecahkan persoalan yang dihadapi anak maupun mengarahkan anak dalam menggali potensinya; guru sebagai pelatih, mengembangkan keterampilan-keterampilan pada anak didik untuk membentuk kompetensi dasar sesuai potensinya. guru sebagai penilai, penilaian dari guru menjadi penentu dalam pencapaian tujuan pembelajaran peserta didik.

Guru memiliki peran yang sangat penting dalam menanamkan nilai toleransi dengan mengintegrasikan pendidikan dengan berbagai budaya. Perilaku seorang guru di kelas menjadi kunci dalam membantu semua siswanya mencapai potensi tanpa memandang jenis kelamin, etnis, usia, agama, bahasa atau keistimewaan (Sosyal et al., 2011).Berikut adalah peran guru menurut Lickona, Schaps, Lewis dan Azra dalam (Cahyaningrum et al., 2017) dalam menanamkan nilai-nilai karakter salah satunya nilai toleransi antara lain: dalam usaha menanamkan karakter pada anak, pendidik harus terlibat secara langsung dalam proses baik kegiatan pembelajaran maupun kegiatan lainnya; pendidik atau guru bertanggungjawab menjadi contoh atau teladan yang memiliki nilai-nilai karakter termasuk nilai toleransi dan memberikan pengaruh kepada peserta didik; guru harus dapat memberikan arahan kepada peserta didik bahwa karakter peserta didik tumbuh melalui kerjasama dalam mengambil keputusan; guru harus sering melakukan refleksi rutin mengenai masalah-masalah moral yang berkembang serta memastikan perkembangan karakter peserta didik secara berkelanjutan; endidik perlu menjelaskan dan mengklarifikasi kepada peserta didik secara berkesinambungan mengenai berbagai nilai-nilai yang baik maupun yang buruk.

Guru merupakan komponen penting dalam meningkatkan mutu pendidikan (Djollong \& Akbar, 2019). Guru berperan dalam menanamkan nilai-nilai karakter pada anak ketika anak berada di sekolah. Sekolah menjadi lingkungan yang sangat mempengaruhi tumbuh kembang dan karakter anak. Lembaga sekolah atau khususnya pendidik di sekolah berperan penting dalam menanamkan nilai-nilai karakter salah satunya adalah nilai toleransi.

Hasil sebuah penelitian menunjukkan sikap toleransi pada anak di TK ABA Melati Medan belum mendapatkan pendidikan karakter secara maksimal di kelas, guru belum bisa menyeimbangkan antara pembelajaran kognitif dengan pembelajaran karakter salah satunya nilai toleransi, untuk itu peneliti meningkatkan sikap toleransi anak dengan menerapkan kegiatan mendongeng. Pada penelitian ini diberikan tindakan dengan dua siklus, pada siklus pertama nilai rata-rata toleransi anak yaitu 54,11 sedangkan pada siklus kedua terjadi peningkatan nilai rata-rata menjadi 81,17 . Pada penelitian ini indikator toleransi yang nilai adalah membedakan perbuatan baik dan buruk, menunjukkan perilaku mulia (sopan santun dan hormat) dan perilaku baik berhubungan dengan orang lain (Ratnawati, 2016). Untuk itu diharapkan pendayaan kompetensi guru secara optimal dan proporsional disertai komitmen dalam memberikan teladan kepada anak akan mewujudkan toleransi pada anak usia dini yang diharapkan (Jumiatmoko, 2018).

Pengembangan toleransi khususnya toleransi beragama juga dilakukan di Taman Kanak-Kanak Negeri Pembina Kota Denpasar Bali dimana lembaga TK ini melaksanakan pembelajaran untuk mengembangkan perilaku toleransi beragama. Penelitian ini menggunakan pendekatan studi kasus dengan cara mengumpulkan data tentang pelaksanaan strategi toleransi beragama di TK Negeri Pembina Kota Denpasar berupa dokumentasi, wawancara dan observasi. Penelitian ini mendapatkan hasil temuan yaitu toleransi anak usia 5-6 tahun meliputi aspek kedamaian, menghargai perbedaan. Peran guru dalam 
mengembangkan toleransi beragama sangat besar karena pada hasil penelitian ini disimpulkan bahwa toleransi beraga,a anak usia dini usia 5-6 tahun di TK Negeri Pembina Kota Denpasar berkembang dengan sangat baik (Nadar et al., 2019).

Fatimah pada penelitiannya di RA Bakti XV di Surakarta berdasarkan hasil observasi ditunjukkan bagaimana cara guru dalam menanggapi peristiwa intoleran khususnya intoleransi verbal. Yang guru lakukan antara lain selalu mengajak siswa menggunakan kata "maaf, tolong, dan terimakasih", menghormati sesama dengan cara bersalaman dan membungkukkan badan, mengajak anak menirukan ujaran-ujaran sopan dan perbuatan terpuji (Fatimah, 2018). Adapula strategi pembelajaran yang guru upayakan di PAUD Widya Dharma Banjarmasin yaitu melalui kegiatan, seperti mengenalkan sifat-sifat baik pada anak, mengenalkan sifat-sifat toleransi, mengupayakan anak tidak hanya tahu sifat-sifat itu melainkan memahaminya, menstimulasi secara terus-menerus agar anak semakin memahami dan rasa toleransi itu tertanam pada diri anak dan membuat anak merasakan manfaat sifat toleransi (Zain, 2020).

Upaya yang guru lakukan dalam pelaksanaan pendidikan mulitkultural dalam membentuk karakter anak khususnya nilai toleransi di TK Negeri Pembina Kecamatan Trimurjo Kabupaten Lampung Tengah melalui kegiatan sehari-hari di sekolah antara lain yaitu, mengadakan program pengembangan diri, pengintegrasian dalam kegiatan pembelajaran, membangun budaya di sekolah, contoh nyata pelaksanaan kegiatan untuk menanamkan nilai toleransi adalah mengadakan lomba baju adat daerah untuk memperingati Hari Kartini, dengan adanya kegiatan ini anak dikenalkan keberagaman yang ada di Indonesia (Hasanah, 2018).

\section{Metode dalam menanamkan nilai toleransi pada anak usia dini}

Seperti yang dijelaskan beberapa hasil penelitian di atas, untuk menanamkan nilai toleransi pada anak usia dini diperlukan sebuah strategi atau cara-cara yang tepat dan efektif agar tujuan dalam menanamkan nilai toleransi pada anak usia dini tercapai. Guru sebagai fasilitator dalam menanamkan nilai-nilai karakter salah satunya nilai toleransi, baik di dalam kegiatan pembelajaran maupun diluar pembelajaran.

Untuk membentuk karakter anak agar rasa toleransi itu terpatri dalam jiwa maka anak harus melihat contoh itu disekelilingnya. Sedangkan untuk pembiasaan sangat efektif digunakan kepada anak usia dini agar nilai itu semakin tertanam dan tidak akan goyah dikemudian hari (Cahyaningrum et al., 2017).Metode teladan dan pembiasaan dalam menanamkan nilai-nilai toleransi juga dilaksanakan oleh Kiddy Care Tegal. Guru memberikan contoh langsung sehingga harapannya anak bisa langsung mempraktikan sikap-sikap positif yang dicontohkan. Guru juga membiasakan anak untuk berinteraksi dengan lingkungan sekitar (Faiqoh, 2015).

Keteladanan dan pembiasaan merupakan unsur yang sangat penting dalam proses melakukan sikap perilaku anak. Pendidik atau guru sudah seharusnya menjadi contoh utama sebelum menanamkan karakter pada anak (Lestaningrum \& Jayanti, 2019).Para guru di PAUD Widya Dharma Banjarmasin juga menampilkan sifat toleransi dengan saling tolong menolong dan saling berteman tanpa membedakan, dengan harapan keteladaan ini dapat dicontoh oleh anak-anak (Zain, 2020).

Metode untuk menanamkan nilai toleransi pada anak juga bisa dengan menggunakan media. Pembelajaran dengan memanfaatkan media membuat anak menjadi lebih mudah memahami dan mengikuti kegiatan pemeblajaran. Seperti pada hasil penelitian dalam meningkatkan sikap menghargai pada anak usia 5-6 tahun di TK Sinar Pagi Tulungagung, media wayang mampu meningkatkan sikap menghargai anak (Lestaningrum \& Jayanti, 2019). Media lainnya seperidiversity doll. Berdasarkan hasil penelitianpenggunaan media ini terbukti efektif untuk menanamkan toleransi pada anak usia 4-5 tahun di RaudhotilAthfal 02 Mangunsari Semarang (Soraya, 2013). 
Guru di Taman Kanak-Kanak Town For Kids Pontianak Tenggara juga menggunakan media dalam mengupayakan penanaman nilai toleransi pada anak usia dini, berbagai media tersebut antara lain yaitu buku cerita, barang-barang bekas, televise, tape recorder. Mediamedia tersebut berdasarkan hasil penelitian ternyata mampu menumbuhkan sikap toleransi bagi anak (Sipa, 2016). Buku cerita juga termasuk media sebagai sarana pembelajaran karakter salah satunya nilai toleransi dan mampu mempererat hubungan guru dan anak, maka dirancnglah buku cerita tentang pendidikan karakter toleransi dan cinta damai untuk anak usia 3-5 tahun (Babuta et al., 2014).

Guru atau pendidik di PAUD Mawar I SKB Ogan Ilir juga menanamkan nilai toleransi pada anak dengan menggunakan media yaitu alat permainan edukatif. Dengan menggunakan alat permainan edukatif memberikan kebebasan kepada anak untuk bermain dan belajar, menumbuhkan sikap kerja sama dan saling menghargai antar teman, saling mendengarkan pendapat masing-masing sehingga mampu mengurangi atau menghilangkan kebiasaan sikap mengejek pada diri anak (Hakim \& Husin, 2019).

Metode lain yang bisa diaplikasikan untuk menanamkan nilai toleransi ialah melalui permainan. Berdasarkan hasil penelitian yang dilakukan pada Anak-anak Usia Dini di Wilyahah RW 01 Kelurahan Playon, Kecamatan Pasar Rebo Jakarta Timur, permainan outdoor yang bersifat edukatif mampu memberikan kesempatan kepada anak untuk menanamkan nilai-nilai karakter salah satunya nilai toleransi, dimana melalui permainan anak dapat belajar menghargai perbedaan dengan teman-temannya (T. U. Dewi \& Handayani, 2019).Permainan lainnya yang digunakan untuk menanamkan nilai toleransi pada anak yaitu permainan tradisional. Permainan tradisional berkelompok yang rancang oleh guru untuk kegiatan anak di RA PSM NgronggorNganjuk bertujuan melatih anak untuk memiliki sikap toleransi antar sesama dan dapat bekerjasama dengan teman tanpa membeda-bedakan (M. K. Dewi, 2019).

\section{SIMPULAN}

Guru memiliki peran penting dalam menanamkan nilai toleransi pada anak usia dini. Peran tersebut di Indonesia adalah dengan merancang kurikulum toleransi, memiliki kompetensi yang optimal dan proporsional serta memiliki komitmen yang kuat dalam memberikan teladan kepada anak mengenai nilai-nilai karakter salah satunya nilai toleransi. Selain itu penanaman nilai toleransi dilakukan melalui kegiatan pembelajaran dengan metode seperti memberikan keteladanan, pemberian arahan, pembiasaan, kegiatan mendongeng, kegiatan permainan, dan penggunaan media.

\section{UCAPAN TERIMAKASIH}

Penulis mengucapkan terima kasih kepada semua penulis artikel terhadulu yang sudah memberikan banyak sumber kepada artikel ini sehingga artikel kajian literasi ini dapat disusun dengan baik, kemudian kepada dosen pembimbing yang telah membantu dalam menyusun artikel ini sehingga dapat diterima dan dipublikasikan dan juga semya pihak yang telah membantu dalam proses pembuatan artikel jurnal ini yang tidak dapat disebutkan satu persatu, semoga mendapatkan balasan dari Allah SWT. Aamiin.

\section{DAFTAR PUSTAKA}

Ananda, R. (2017). Implementasi Nilai-nilai Moral dan Agama pada Anak Usia Dini. Jurnal Obsesi: Jurnal Pendidikan Anak Usia Dini, 1(1), 19. https://doi.org/10.31004/obsesi.v1i1.28

Anang, \& Zuhroh, K. (2019). Nilai-Nilai Toleransi Antar Sesama dan Antar Umat Beragama (Studi Pandangan Kh. Sholeh Bahruddin). Multicultural Islamic Education, 3(1), 41-55. https://doi.org/10.35891/ims.v3i1.1730

Ati, S. (2015). Analisis Literasi Informasi Pemakai Taman Bacaan Masyarakat. Jurnal Kajian Informasi dan Perpustakaan, 3(1), 89. https:// doi.org/10.24198/jkip.v3i1.9492 
Babuta, Y., Babuta, Y. Y. I., \& Wahyurini, O. D. (2014). Perancangan Buku Pendidikan Karakter Toleransi dan Cinta Damai untuk Anak Usia 3-5 Tahun. Jurnal Sains dan Seni ITS, 3(1), F28-F32. http://www.ejurnal.its.ac.id/index.php/sains_seni/article/view/6060

Cahyaningrum, E. S., Sudaryanti, S., \& Purwanto, N. A. (2017). Pengembangan Nilai-Nilai Karakter Anak Usia Dini Melalui Pembiasaan Dan Keteladanan. Jurnal Pendidikan Anak, 6(2), 203-213. https:/ / doi.org/10.21831/jpa.v6i2.17707

Dewi, M. K. (2019). Penanaman Nilai Multikultural melalui Permainan Tradisional di RA PSM Ngronggot Nganjuk. Jurnal Penelitian Islam, 13. https://doi.org/10.21154/kodifikasia.v13i2.1846

Dewi, T. U., \& Handayani, S. L. (2019). Penanaman Nilai Karakter Melalui Permainan Outdoor Bagi Anak-Anak Usia Dini di Wilayah RW 01 Kelurahan Pekayon Kecamatan Pasar Rebo Jakarta Timur. Publikasi Pendidikan, 9(1), 1. https:// doi.org/10.26858/publikan.v9i1.6418

Djollong, A. F., \& Akbar, A. (2019). Peran Guru Pendidikan Agama Islam Dalam Penanaman Nilai-Nilai Toleransi Antar Ummat Beragama Peserta Didik Untuk Mewujudkan Kerukunan. Al-'Ibrah: Jurnal Pemikiran dan Pendidikan Islam, 8(1), 72-92. https://www.umpar.ac.id/jurnal/index.php/ibrah/article/view/22

Fadhillah, N. (2019). Pentingnya Pendidikan Anak Usia Dini Bagi Tumbuh Kembang Anak. Jurnal Dinamika Pendidikan Dasar, 8(235), 245. https://doi.org/10.31219/osf.io/3j9qb

Faiqoh, N. (2015). Implementasi Pendidikan Berbasis Multikultural Sebagai Upaya Penguatan Nilai Karakter Kejujuran, Toleransi, Dan Cinta Damai Pada Anak Usia Dini Di Kiddy Care, Kota Tegal. BELIA: Early Childhood Education Papers, 4(2), 78-85.

Faridah, I. F. (2013). Toleransi Antarumat Beragama Masyarakat Perumahan. Komunitas: International Journal of Indonesian Society and Culture, 5(1), 14-25. https:// doi.org/10.15294/komunitas.v5i1.2368

Fatimah, N. (2018). Apresiasi Kebinekaan Melalui Pembelajaran Penggunaan Ujaran Toleran (Verbal Tolerance) Pada Siswa Usia Dini. Kongres Bahasa Indonesia.

Hakim, I. A., \& Husin, A. (2019). Pendidikan Karakter Pada Anak Usia Dini (Studi Kasus di PAUD Mawar I SKB Ogan Ilir). Jurnal Pendidikan dan Pemberdayaan Masyarakat UNSRI.

Hasanah, U. (2018). Implementasi Pendidikan Multikultural dalam Membentuk Karakter Anak Usia Dini. Golde Age: Jurnal Pendidikan Anak Usia Dini, 2(1), 35-53. https:// doi.org/10.29313/ga.v2i1.3990

Hjerm, M., Eger, M. A., Bohman, A., \& Fors Connolly, F. (2020). A New Approach to the Study of Tolerance: Conceptualizing and Measuring Acceptance, Respect, and Appreciation of Difference. Social Indicators Research, 147(3), 897-919. https:// doi.org/10.1007/s11205-019-02176-y

Idris, F., Abdullah, M. R. N., Ahmad, A. R., \& Mansor, A. Z. (2016). The Effect of Religion on Ethnic Tolerance in Malaysia: The Application of Rational Choice Theory (RCT) and the Theory of Planned Behaviour (TPB). International Education Studies, 9(11), 13. https:// doi.org/10.5539/ies.v9n11p13

Janmaat, J. G., \& Keating, A. (2019). Are today's youth more tolerant? Trends in tolerance among young people in Britain. Ethnicities, 19(1), 44-65. https:/ / doi.org/10.1177/1468796817723682

Juanda, J. (2019). Pendidikan Karakter Anak Usia Dini melalui Sastra Klasik Fabel Versi Daring. Jurnal Obsesi: Jurnal Pendidikan Anak Usia Dini, 3(1), 39. https:// doi.org/10.31004/obsesi.v3i1.126

Jumiatmoko. (2018). Peran guru dalam pengembangan sikap toleransi beragama pada anak usia dini. Thufula: Jurnal Inovasi Pendidikan Guru Raudhatul Atfal, 6. https:// doi.org/10.31227/osf.io/tnc5b

Lestaningrum, A., \& Jayanti, R. D. (2019). Penggunaan Media Wayang Godong Dalam Menanamkan Karakter Menghargai Pada Anak Usia 5-6 Tahun. KINDERGARTEN: Journal of Islamic Early Childhood Education, 2(1), 15. 
DOI: 10.31004/obsesi.v5i2.972

https:// doi.org/10.24014/kjiece.v2i1.8112

Lestari, G. (2015). Bhinnekha Tunggal Ika: Khasanah Multikultural Indonesia di Tengah Kehidupan Sara. Jurnal Pendidikan Pancasila dan Kewarganegaraan, 28(1), 31-37.

Liulka, H. (2019). The Features of Tolerance in Parent-Child Relationship. The Features of Tolerance in Parent-Child Relationship, 155-157. https:/ / doi.org/10.30525/978-9934-58811-2_52

Manoppo, F. K., Janis, Y., \& Wuwung, O. (2019). Tolerance Education for Early Childhood in Industry 4.0. 339(Aicosh), 294-297. https:// doi.org/10.2991/aicosh-19.2019.64

Nadar, W., Mansoer, Z., \& Bayanie, M. (2019). Pengembangan Toleransi Beragama Anak Usia Dini di TK Negeri Pembina Kota Denpasar Bali. Jurnal Ilmu Pendidikan (JIP) STKIP Kusuma Negara, 11(1), 37-52.

Nasution, N., Yaswinda, Y., \& Maulana, I. (2019). Analisis Pembelajaran Berhitung melalui Media Prisma Pintar pada Anak Usia Dini. Jurnal Obsesi : Jurnal Pendidikan Anak Usia Dini, 4(1), 240. https:// doi.org/10.31004/obsesi.v4i1.311

Ozkul, A. E., Ozsezer, M., \& Tufan, H. (2018). The historical background of tolerance education for blind learners in Cyprus. Quality and Quantity, 52, 1007-1025. https://doi.org/10.1007/s11135-017-0554-z

Prabowo, M. S. (2019). Penanaman Nilai Bertoleransi dalam Kehidupan Kebebasan Beragama Bagi Siswa Sekolah Menengah. Jurnal Pengabdian Hukum Indonesia, 1, 101-122.

Putry, R. (2019). Nilai Pendidikan Karakter Anak Di Sekolah Perspektif Kemendiknas. Gender Equality: International Journal of Child and Gender Studies, 4(1), 39. https:// doi.org/10.22373/equality.v4i1.4480

Ratnawati, S. (2016). Penerapan Kegiatan Mendongeng Dalam Meningkatkan Sikap Toleransi Pada Anak Usia 5-6 Tahun Di Tk Aba Melati. Elementary School Journal Pgsd Fip Unimed, 6(2), 97-105. https://doi.org/10.24114/esjpgsd.v6i2.5978

Sahal, M., Musadad, A. A., \& Akhyar, M. (2018). Tolerance in Multicultural Education: A Theoretical Concept. International Journal of Multicultural and Multireligious Understanding, 5(4), 115. https:// doi.org/10.18415/ijmmu.v5i4.212

Salim, A. N. (2018). Penanaman Nilai Toleransi Antar Umat Beragama Di Kalangan Masyarakat Kecamatan Mlati Kabupaten Slemans (Nomor March). http:/ / repository.upy.ac.id/1721/

Schweitzer, F. (2018). Education for Tolerance. In Religious Education (hal. 19-34). https://doi.org/10.1007/978-3-658-21677-1_2

Sipa, S. P. ; M. (2016). Upaya Guru Menumbuhkan Sikap Toleransi Bagi Anak Usia Dini. Jurnal Pendidikan dan Pembelajaran, 5(6), 1-11.

Soraya, S. (2013). Studi eksperimen penggunaan media diversity doll dan media gambar sebagai penanaman sikap toleransi anak usia 4-6 tahun di raudhotul athfal 02 mangunsari semarang. Indonesian Journal of Early Childhood Education Studies, 2(2). https://doi.org/10.15294/ijeces.v2i2.9239

Sosyal, U., Dergisi, A., Tarman, I., \& Tarman, B. (2011). Developing effective multicultural practices: A case study of exploring a teacher's understanding and practices. The Journal of International Social Research, 4(17), 1-21.

Susanto, E. F., \& Kumala, A. (2019). Sikap Toleransi Antaretnis. Tazkiya Journal of Psychology, 7(2), 105-111. https:// doi.org/10.15408/tazkiya.v7i2.13462

Taş, H., \& Minaz, M. B. (2019). The Impact of Biography-based Values Education on 4th Grade Elementary School Students' Attitudes towards Tolerance Value. International Journal of Progressive Education, 15(2), 118-139. https:// doi.org/10.29329/ijpe.2019.189.9

Wandi, Z. N., \& Mayar, F. (2019). Analisis Kemampuan Motorik Halus dan Kreativitas pada Anak Usia Dini melalui Kegiatan Kolase. Jurnal Obsesi : Jurnal Pendidikan Anak Usia Dini, 4(1), 363. https:// doi.org/10.31004/obsesi.v4i1.347

Zain, A. (2020). Strategi Penanaman Toleransi Beragama Anak Usia Dini. PAUD Lectura: Jurnal Pendidikan Anak Usia Dini, 4(01), 97-111. https://doi.org/10.31849/paudlectura.v4i01.4987 